\title{
FACTORS INFLUENCING TOURISTS' TRAVEL EXPERIENCE SHARING ON SOCIAL MEDIA
}

\author{
Retno Widiana ${ }^{*} 1$, Santi Novani*) \\ ${ }^{*}$ School of Business and Management, Institut Teknologi Bandung \\ Jl. Ganesa No.10, Lb. Siliwangi, Bandung, West Java, 40132, Indonesia
}

\begin{abstract}
As travel-related content of tourist experiences benefits for both tourists to consume information online and for companies by providing insight into how visitors perceive their services, it becomes critical to understand the antecedents of travel experience sharing on social media. The study aims to develop a model of overall satisfaction, perceived enjoyment, motivations, and inhibitor toward sharing travel experiences, where personality factors impact overall satisfaction and perceived enjoyment. Partial Least Squares analysis was performed to evaluate the last experience of 169 Indonesian tourists in Bandung. The study discovers that conscientiousness and openness to experience trait is significant predictor of overall experience satisfaction, and only extraversion trait is identified as a significant predictor of perceived enjoyment. When it comes to predicting travel experience sharing on social media, overall satisfaction, perceived enjoyment, personal fulfillment, and self-actualization reasons have been significant predictors, but altruistic motivations and security and privacy concerns have not. Destination managers should be aware of different travelers' personalities that could impact their satisfaction and perceived enjoyment, influencing their sharing experience behavior. Personalized service and promotion can increase contributors to sharing travelrelated content on social media.
\end{abstract}

Keywords: personality traits, overall satisfaction, perceived enjoyment, travel experience sharing, PLS-SEM

\begin{abstract}
Abstrak: Karena konten pengalaman wisata yang terkait dengan perjalanan bermanfaat baik bagi wisatawan untuk mengonsumsi informasi secara daring maupun bagi perusahaan dengan memberikan wawasan tentang bagaimana pengunjung memandang layanan mereka, maka memahami anteseden berbagi pengalaman perjalanan di media sosial menjadi hal yang penting. Tujuan penelitian ini adalah untuk mengembangkan model kepuasan keseluruhan, kenikmatan yang dirasakan, motivasi, dan penghambat dalam berbagi pengalaman perjalanan, di mana kepuasan keseluruhan dan kenikmatan yang dirasakan dipengaruhi oleh faktor kepribadian. Analisis Partial Least Squares dilakukan untuk mengevaluasi pengalaman terakhir 169 wisatawan Indonesia di Bandung. Studi ini menemukan bahwa jenis kepribadian kehati-hatian dan keterbukaan terhadap pengalaman adalah prediktor signifikan dari kepuasan pengalaman secara keseluruhan, dan hanya jenis kepribadian ekstraversi yang diidentifikasi sebagai prediktor signifikan dari kenikmatan yang dirasakan. Prediktor signifikan berbagi pengalaman perjalanan di media sosial yakni kepuasan keseluruhan, kenikmatan yang dirasakan, serta pemenuhan pribadi dan alasan aktualisasi diri. Motivasi altruistik dan masalah keamanan dan privasi ditemukan tidak mempengaruhi berbagi pengalaman perjalanan di sosial media. Manajer destinasi harus menyadari kepribadian wisatawan yang berbeda dapat memengaruhi kepuasan dan kenikmatan yang dirasakan yang pada gilirannya memengaruhi perilaku berbagi pengalaman mereka. Layanan yang dipersonalisasi dan promosi dapat ditawarkan untuk meningkatkan kontributor berbagi konten terkait perjalanan di media sosial.
\end{abstract}

Kata kunci: ciri-ciri kepribadian, kepuasan keseluruhan, kenikmatan yang dirasakan, berbagi perjalanan perjalanan, PLS-SEM

\footnotetext{
${ }^{1}$ Corresponding author:

Email: retno-widiana@sbm-itb.ac.id
} 


\section{INTRODUCTION}

The shift fromfirm-centric to individual-centric business logic, product and service offering to experience the environment changes the role of information and technologies (ITs) in business practices (Ramaswamy, 2005). Travelers can act as users of technologies, coproducer of meaningful experiences, and storytellers (Gretzel et al. 2006). Storytelling about experiences can help tourists remember and give them meaning (Gretzel et al. 2006). Travelers can now use various media technologies to tell their stories, such as social media and even commenting on the tourism provider's promises (Buhalis and Inversini, 2014).

Younger travelers use Instagram and Facebook more (TripAdvisor, 2016). According to Kemp (2021), Indonesians used social media at a rate of $61.8 \%$ in January 2021. According to the same report, Indonesians use Youtube, WhatsApp, Instagram, Facebook, and Twitter, with Youtube having the most users. Millennials are aged 18-24 and 25-44 dominate as users (Kemp, 2021). Younger travelers or Millenials averaged have personal income, are more likely to allocate leisure activities, and are independent decisionmakers (Kaihatu et al. 2020).

However, social mediais used more forconsumption(e.g. trip planning) than producing (e.g. sharing experience, posting, review). Regrettably, only $17 \%$ of travelers have ever posted travel-related content on the internet (Yoo and Gretzel, 2011). Understanding antecedents why tourists would generate content regarding their travel experience would benefit potential travelers and businesses. Numerous studies have been carried out mainly focuses on social media posts and storytelling as tools for co-create value, information adoption from social media, tourists' motivations, cost-benefit effect, and social influence (Sorensen et al. 2017; Üçok Hughes et al. 2016; Chung et al. 2015; Chung and Koo, 2015; Munar and Jacobsen, 2014; Wang and Li, 2017; Kang and Schuett, 2013; Kumar et al. 2020; Oliveira et al. 2020; Wilson et al. 2012; Bakshi et al. 2021) but lacking in pinpointing at the personality features that might be a potential predictor. Several studies found that personality traits influence technology use (Devaraj et al.2008; Ehrenberg et al.2008) and technology acceptance (Özbek et al.2014).
To know the antecedent why tourists would be social media creators, previous research has found that perceived enjoyment is a significant predictor. Kang and Schuett (2013) and Oliveira et al. (2020) have tested perceived enjoyment as a mediating role to understand why travelers do the sharing. As perceived enjoyment gained substantial attention, the role of overall experience satisfaction to predict sharing experience behavior becomes a potential area to be tested since previous research fails to appoint their relationship. Thus, the present study aims to develop a model of overall satisfaction, perceived enjoyment, motivations, and inhibitor towards travel experience sharing, where personality traits influence satisfaction and perceived enjoyment. The approach used to achieve the objective is implementing a quantitative study using PLS-SEM analysis.

Due to the scope of this research, the context of the study is limited to Indonesian tourists visiting Bandung tourist destinations during the past year (2020-2021). Bandung is considered a multi-attraction destination is encompassing culture and heritage, history and education, shopping center and local foods, and even nature-based tourism destinations. Historical data of several Indonesian Tourist Trips in 2015-2019 showed that the highest average number of tourist arrival in Indonesia is centralized in West Java Province (BPS, 2021), with the highest average number of tourists centralized in Karawang, Bandung, and West Bandung (BPS, 2021). Therefore, Bandung is a potential tourist destination to be developed in Indonesia.

As storytelling facilitates value co-creation behavior (Yi and Gong, 2013), and reflect the experience after the trip (Pera, 2017), this study will contribute to the body of knowledge of value co-creation based on the exchange of experiences and its relationship with personal differences, experience satisfaction, as well as motivations and inhibitor. The current study will also enhance destination managers' understanding of what drivers will benefit them to facilitate interaction with tourists and understand traveler experience to enhance their service quality.

\section{METHODS}

Quantitative research was employed to enable the generalization of the result. Data were obtained in August 2021 by sending an online survey to millennials 
who use Facebook, Instagram, Twitter, personal blogs/ websites, TikTok and/or YouTube. The study's target is domestic tourists, and a questionnaire was compiled using Bahasa. The study's participants are Indonesian tourists who have recently visited Bandung (20202021). The survey included 169 domestic tourists. Data were analyzed using PLS-SEM. The number of samples is qualified with the 10 times rule by Barclay et al. (1995). PLS-SEM is preferred over covariancebased SEM for theory testing, and it easily integrates reflective and formative measurement methods (Hair et al. 2017).

We follow Yoo and Gretzel (2011) who used 5 selfdescriptive phrase items from the International Personality Item Pool (IPIP, 2008; Goldberg, 1999) to measure personality traits. Perceived enjoyment scale adapted from Amaro et al. (2016), and overall satisfaction scale adapted from Liu et al. (2017).
Altruistic motivations, personal fulfillment and selfactualization, and security and privacy reasons are adapted from Oliveira et al. (2020). The items were measured on a 5-point Likert scale ranging from 1-Strongly Disagree to 5-Strongly Agree. Travel experience sharing scale adapted from Amaro et al. (2016) and measured using a 5-point Likert scale, ranging from 1-Never to 5-Always. The detailed items are provided in Table 1.

We hypothesized that personality traits would influence overall satisfaction and perceived enjoyment of sharing travel experiences. In contrast, travel experience sharing is influenced by overall satisfaction, perceived enjoyment, altruistic motivations, personal fulfillment and self-actualization, as well as security and privacy reasons. The conceptual model is provided in Figure 1 .

Table 1. Constructs and Items

\begin{tabular}{|c|c|c|}
\hline Constructs & Item & Measurement \\
\hline \multicolumn{3}{|l|}{ Personality Traits } \\
\hline \multirow{5}{*}{$\begin{array}{l}\text { Extraversion } \\
\text { (IPIP, 2008; Goldberg, 1999) }\end{array}$} & Ext1 & I talk a lot to different people during my trip \\
\hline & Ext2 & I feel comfortable around people \\
\hline & Ext3 & I start conversations \\
\hline & Ext4 & I make friends easily \\
\hline & Ext5 & I do not mind being the center of attention \\
\hline \multirow{5}{*}{$\begin{array}{l}\text { Agreeableness (Ag) (IPIP, 2008; } \\
\text { Goldberg, 1999) }\end{array}$} & Ag1 & I sympathize with others' feelings \\
\hline & $\operatorname{Ag} 2$ & I am concerned about others \\
\hline & $\mathrm{Ag} 3$ & I respect others \\
\hline & Ag4 & I believe that others have good intentions \\
\hline & $\operatorname{Ag} 5$ & I trust what people say \\
\hline \multirow{5}{*}{$\begin{array}{l}\text { Conscientiousness (Con) (IPIP, 2008; } \\
\text { Goldberg, 1999) }\end{array}$} & Con 1 & I carry out my plans \\
\hline & Con2 & I pay attention to details \\
\hline & Con3 & I am always prepared \\
\hline & Con4 & I make plans and stick to them \\
\hline & Con5 & I am exacting in my work \\
\hline \multirow{5}{*}{$\begin{array}{l}\text { Neuroticism (Neu) } \\
\text { (IPIP, 2008; Goldberg, 1999) }\end{array}$} & Neu1 & I get stressed out easily \\
\hline & Neu2 & I worry about things \\
\hline & Neu3 & I fear for the worst \\
\hline & Neu4 & I am filled with doubts about things \\
\hline & Neu5 & I panic easily \\
\hline \multirow{5}{*}{$\begin{array}{l}\text { Openness to Experience (Op) } \\
\text { (IPIP, 2008; Goldberg, 1999) }\end{array}$} & Op1 & I get excited by new ideas \\
\hline & Op2 & I enjoy thinking about things \\
\hline & Op3 & I enjoy hearing new ideas \\
\hline & Op4 & I enjoy looking for a deeper meaning in things \\
\hline & Op5 & I have a vivid imagination \\
\hline
\end{tabular}


Table 1. Constructs and Items (continue)

\begin{tabular}{|c|c|c|}
\hline Constructs & Item & Measurement \\
\hline \multirow{4}{*}{$\begin{array}{l}\text { Perceived Enjoyment (Per) } \\
\text { (Amaro et al. 2016) }\end{array}$} & Per1 & Using social media for sharing my travel experience is enjoyable \\
\hline & Per2 & Using social media for sharing my travel experience is fun \\
\hline & Per3 & $\begin{array}{l}\text { Using social media for sharing my travel experience stimulates my } \\
\text { curiosity }\end{array}$ \\
\hline & Per4 & $\begin{array}{l}\text { I consider the use of social media for sharing my travel experience a } \\
\text { big hassle }\end{array}$ \\
\hline \multirow{3}{*}{$\begin{array}{l}\text { Overall Satisfaction (Sat) } \\
\text { (Liu et al. 2017) }\end{array}$} & Sat1 & I enjoyed my last trip to Bandung \\
\hline & Sat2 & My choice to visit Bandung was a wise one \\
\hline & Sat3 & This tourism experience in Bandung is exactly what I expected \\
\hline \multirow{7}{*}{$\begin{array}{l}\text { Travel Experience Sharing (Exp) } \\
\text { (Amaro et al. 2016) }\end{array}$} & & After the Trip \\
\hline & Exp1 & I write hotel reviews on social media \\
\hline & Exp2 & I post photos/videos on social media \\
\hline & Exp3 & I write reviews of activities/attractions on social media \\
\hline & Exp4 & I write reviews of the destination I visited on social media \\
\hline & & During the trip \\
\hline & Exp5 & $\begin{array}{l}\text { I check in to the location I am at/update my location on social media } \\
\text { (for example, on Facebook, Instagram) }\end{array}$ \\
\hline \multirow{3}{*}{$\begin{array}{l}\text { Motivations and Inhibitor } \\
\text { Altruistic Motivations (Alt) } \\
\text { (Oliveira et al. 2020) }\end{array}$} & Alt1 & I want to help others \\
\hline & Alt2 & I want to prevent people from using bad products \\
\hline & Alt3 & I want to contribute to social media that are useful for me \\
\hline \multirow{3}{*}{$\begin{array}{l}\text { Personal Fulfillment and Self-actual- } \\
\text { ization (PS) (Oliveira et al. 2020) }\end{array}$} & PS1 & I want to be recognized because of my travel experiences \\
\hline & PS2 & I want to transmit what I want people to think of me \\
\hline & PS3 & It is important to me that people know I travel \\
\hline \multirow[t]{3}{*}{$\begin{array}{l}\text { Security and Privacy Reasons (SP) } \\
\text { (Oliveira et al. 2020) }\end{array}$} & SP1 & $\begin{array}{l}\text { My requirements for security and privacy are not satisfied by sharing } \\
\text { my travel experiences }\end{array}$ \\
\hline & $\mathrm{SP} 2$ & $\begin{array}{l}\text { I am afraid that sharing my travel experiences will place me in danger } \\
\text { or reveal my personal information }\end{array}$ \\
\hline & SP3 & $\begin{array}{l}\text { One of the main reasons for not sharing my travel experiences is to } \\
\text { preserve privacy and safety }\end{array}$ \\
\hline
\end{tabular}

\section{Personality Traits}

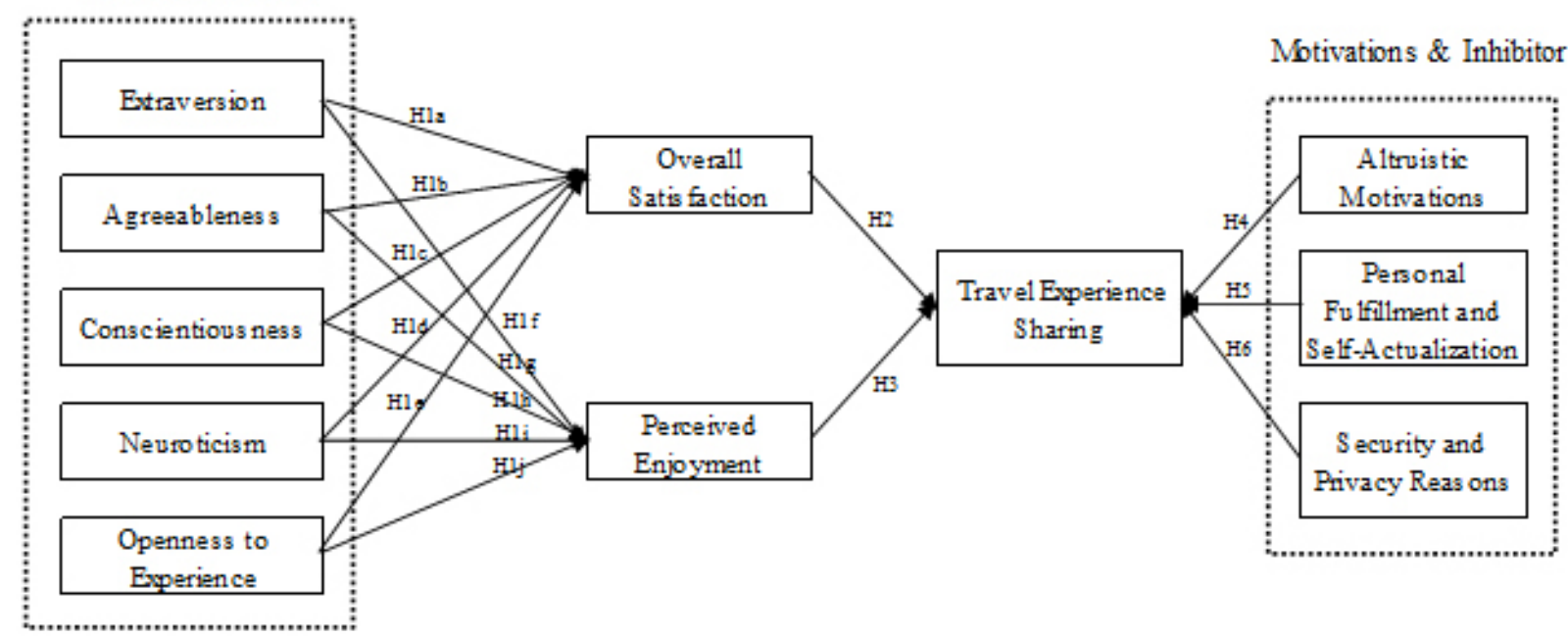

Figure 1. Conceptual model 
H1a: Extraversion is positively related to overall satisfaction

H1b: Agreeableness is positively related to overall satisfaction

H1c: Conscientiousness is positively related to overall satisfaction

H1d: Neuroticism is negatively related to overall satisfaction

H1e: Openness to experience is positively related to overall satisfaction

H1f: Extraversion is positively related to perceived enjoyment

H1g: Agreeableness is positively related to perceived enjoyment

H1h: Conscientiousness is positively related to perceived enjoyment

H1i: Neuroticism is negatively related to perceived enjoyment

H1j: Openness to experience is positively related to perceived enjoyment

$\mathrm{H} 2$ : Overall experience satisfaction will positively impact travel experience sharing on social media.

H3: Perceived enjoyment will positively impact on travel experience sharing on social media.

H4: Altruistic motivations will positively impact on travel experience sharing on social media.

H5: Personal fulfillment and self-actualization will positively impact on travel experience sharing on social media.

H6: Security and privacy reasons will negatively impact on travel experience sharing on social media.

\section{RESULTS}

\section{Respondent Characteristics}

Since the survey was conducted through an online form which enables us to request a complete answer, we got a $100 \%$ usable questionnaire from 169 respondents. Most of the respondents repeat visitors to Bandung as much as $98 \%$, and $2 \%$ are first-timers. $73 \%$ male and $27 \%$ female of the respondents come from the area of West Java (89\%), Central Java (4\%), DKI Jakarta (4\%), East Java (1\%), Bali (1\%), Bangka Belitung Islands (1\%), and Riau Islands (1\%). Top three age group aged 25-30 (56\%), 20-24 (37\%), and 31-40 $(5 \%)$. Most of the respondents are well educated, $78 \%$ of them undergraduate, high school $(10 \%)$, master degree or more $(6 \%)$, and diploma (5\%). Among them, the most frequently used social media are Instagram (83\%), Facebook (5\%), Youtube (5\%), TikTok (4\%), and Twitter (3\%). In visiting Bandung's destinations, the most visited destination category are shopping and culinary destination $(60 \%)$, nature-based destination (38\%), historical and educational destination (2\%), and cultural and heritage destination (1\%).

We used a Partial Least Squares Structural Equation Model (PLS SEM) variance-based to examine the link between constructs. The proposed model consists of reflective and formative items. All constructs are considered reflective items except travel experience sharing, which contains formative items. Both measurement and structural models evaluation will be explained below.

\section{Measurement Models}

To begin, we evaluate the reflective constructs' validity and reliability. Cronbach's alpha and composite reliability should be more than 0.7 when evaluating internal consistency (Hair et al. 2017). According to Table 2, all constructions have values more than 0.7 , with the exception of altruistic motivations, which have a value of 0.651 . We retain the Altruistic and Motivations constructs since a Cronbach's Alpha of 0.6 is deemed acceptable (Chin, 1998).

The outer loading value should preferably be more significant than 0.7. However, if it is less than 0.7, deletion of indicators with outer loading values between 0.40 and 0.70 is permitted only if the deletion raises composite reliability and Average Variance Extracted (AVE) above the threshold value (Hair et al. 2017). Table 3 contains the detailed outer loadings value. We omit Ag4, Ag5, Ext5, Op5, and Per4 since their values are less than 0.6 and their omission improves composite reliability and AVE. The AVE should be greater than 0.5 to determine convergent validity (Hair et al. 2017). According to Table 2, all AVE values match the criterion.

Finally, the Heterotrait-Monotrait (HTMT) criterion, cross-loadings, and the Forner-Larcker criterion are employed to assess discriminant validity. The HTMT values suggest that all constructs are less than the 0.9 criteria, indicating that discriminant validity has been established (Henseler et al. 2015). The criterion for evaluating cross-loadings is that the outer loadings of an indicator on a construct must surpass all cross- 
loadings with other constructs, and the results met this requirement. According to Hair et al. (2017), the square root of the AVE of each construct should be greater than the correlation coefficient of any other construct in the Fornell-Larcker criterion. Once again, the outcome validates the requirement.

The results reveal that all reflective items or indicators met the validity and reliability requirements. Because the model includes formative indicators (Travel Experience Sharing), we test their validity and reliability by looking at their collinearity and outer weights (Hair et al. 2017). Table 4 details the evaluation of the formative indicators. Collinearity of indicators evaluated by Variance Inflation Factor (VIF) should be less than 5 . The results demonstrate that all indicators are less than 5 , indicating that there is no collinearity problem. The weights of all indicators are positive. However, Exp1, Exp3, and Exp4 have p values $>0.05$, indicating insignificance. If the loading factor is $\geq 0.5$, the indicator can be preserved, even if it is insignificant (Hair et al. 2017). The results show that Exp1, Exp3, and Exp4 have loading factors ranging from 0.529 until 0.759 . This signifies that all formative indicators confirmed all requirements.

\section{Structural Models and Hypotheses Testing}

Concerning the evaluation of structural models, first, we assess for collinearity issues based on Variance Inflation Factor (VIF), then evaluate explained variation using $\mathrm{R}^{2}$, significance level, and path coefficient. The VIF value result range from 1.115 to 1.822 which all of the values are below 5 and had no problems with collinearity. The $\mathrm{R}^{2}$ generated a value of 0.616 , which implies the proposed model explains $61.6 \%$ of the variation in travel experience sharing and is considered at a moderate level (Hair et al. 2017). At 5000 iterations, bootstrapping has been executed to generate the significance level. The following hypotheses are accepted from the path coefficient and significance test, the following hypotheses are accepted H1c, H1e, H1f, H2, H3, H5. Meanwhile, H1a, H1b, H1d, H1g, H1h, $\mathrm{H} 1 \mathrm{i}, \mathrm{H} 1 \mathrm{j}, \mathrm{H} 4$, and $\mathrm{H} 6$ are rejected because $\mathrm{p}$ values are higher than 0.05 and t-statistics are lower than 1.96. The conclusion of structural models and hypotheses testing results is provided in Table 5 .

The current study examines the elements that influence travelers' to share their vacation experiences. We hypothesized in the proposed model that perceived enjoyment and overall satisfaction with the experience, motivations and inhibitor factors such as altruistic motivations, personal fulfillment and self-actualization, and security and privacy concerns, all influence people's decision to create travel content on social media. While personality factors have an effect on overall satisfaction and perceived enjoyment.

Table 2. Validity and Reliability

\begin{tabular}{lcccc}
\hline & Cronbach's Alpha & rho_A & Composite Reliability & $\begin{array}{c}\text { Average Variance } \\
\text { Extracted (AVE) }\end{array}$ \\
\hline Altruistic Motivations & 0.707 & 0.711 & 0.837 & 0.632 \\
Conscientiousness & 0.651 & 0.996 & 0.773 & 0.541 \\
Extrovert & 0.768 & 0.776 & 0.843 & 0.519 \\
Neuroticism & 0.798 & 0.812 & 0.869 & 0.624 \\
Openness to Experience & 0.890 & 0.899 & 0.919 & 0.694 \\
Overall Satisfaction & 0.824 & 0.826 & 0.883 & 0.654 \\
Perceived Enjoyment & 0.817 & 0.828 & 0.891 & 0.732 \\
Personal Fulfillment and Self-Actualization & 0.942 & 0.942 & 0.963 & 0.896 \\
Security \& Privacy Reasons & 0.768 & 0.796 & 0.865 & 0.681 \\
Travel Experience Sharing & 0.751 & 0.905 & 0.848 & 0.658 \\
\hline
\end{tabular}


Table 3. Outer Loadings

\begin{tabular}{|c|c|c|c|c|c|c|c|c|c|c|c|}
\hline & $\mathrm{Ag}$ & Alt & Con & Ext & $\mathrm{Neu}$ & $\mathrm{Op}$ & Sat & Per & PS & $\mathrm{SP}$ & Exp \\
\hline Ag1 & 0.854 & & & & & & & & & & \\
\hline Ag2 & 0.771 & & & & & & & & & & \\
\hline Ag3 & 0.757 & & & & & & & & & & \\
\hline Alt1 & & 0.611 & & & & & & & & & \\
\hline Alt2 & & 0.635 & & & & & & & & & \\
\hline Alt3 & & 0.920 & & & & & & & & & \\
\hline Con1 & & & 0.660 & & & & & & & & \\
\hline Con 2 & & & 0.706 & & & & & & & & \\
\hline Con3 & & & 0.785 & & & & & & & & \\
\hline Con4 & & & 0.761 & & & & & & & & \\
\hline Con5 & & & 0.683 & & & & & & & & \\
\hline Exp1 & & & & & & & & & & & 0.529 \\
\hline Exp2 & & & & & & & & & & & 0.888 \\
\hline Exp3 & & & & & & & & & & & 0.759 \\
\hline Exp4 & & & & & & & & & & & 0.712 \\
\hline Exp5 & & & & & & & & & & & 0.754 \\
\hline Ext1 & & & & 0.787 & & & & & & & \\
\hline Ext2 & & & & 0.692 & & & & & & & \\
\hline Ext3 & & & & 0.852 & & & & & & & \\
\hline Ext4 & & & & 0.820 & & & & & & & \\
\hline Neu1 & & & & & 0.770 & & & & & & \\
\hline Neu2 & & & & & 0.888 & & & & & & \\
\hline Neu3 & & & & & 0.822 & & & & & & \\
\hline Neu4 & & & & & 0.858 & & & & & & \\
\hline Neu5 & & & & & 0.823 & & & & & & \\
\hline Op1 & & & & & & 0.822 & & & & & \\
\hline Op2 & & & & & & 0.788 & & & & & \\
\hline Op3 & & & & & & 0.795 & & & & & \\
\hline Op4 & & & & & & 0.829 & & & & & \\
\hline PS1 & & & & & & & & & 0.883 & & \\
\hline PS2 & & & & & & & & & 0.794 & & \\
\hline PS3 & & & & & & & & & 0.796 & & \\
\hline Per1 & & & & & & & & 0.961 & & & \\
\hline Per2 & & & & & & & & 0.954 & & & \\
\hline Per3 & & & & & & & & 0.923 & & & \\
\hline SP1 & & & & & & & & & & 0.598 & \\
\hline SP2 & & & & & & & & & & 0.872 & \\
\hline SP3 & & & & & & & & & & 0.925 & \\
\hline Sat1 & & & & & & & 0.828 & & & & \\
\hline Sat2 & & & & & & & 0.895 & & & & \\
\hline Sat3 & & & & & & & 0.842 & & & & \\
\hline
\end{tabular}


Table 4. Formative measurement indicators evaluation

\begin{tabular}{lccccc}
\hline Formative Construct & Item & Weight & P Values & Loading Factor & VIF \\
\hline \multirow{4}{*}{ Travel Experience Sharing } & Exp1 & 0.148 & 0.091 & 0.529 & 1.362 \\
& Exp2 & 0.572 & 0.000 & 0.888 & 1.583 \\
& Exp3 & 0.092 & 0.431 & 0.759 & 3.186 \\
& Exp4 & 0.176 & 0.102 & 0.712 & 2.806 \\
& Exp5 & 0.290 & 0.001 & 0.754 & 1.523 \\
\hline
\end{tabular}

Table 5. The results of structural models and hypotheses testing

\begin{tabular}{ccccc}
\hline Path & $\beta$ & T Statistics & P-Value & Decision \\
\hline Ext $\rightarrow$ Sat & 0.102 & 1.257 & 0.209 & H1a Rejected \\
$\mathrm{Ag} \rightarrow$ Sat & 0.112 & 1.382 & 0.167 & H1b Rejected \\
$\mathrm{Con} \rightarrow$ Sat & 0.250 & 3.250 & 0.001 & H1c Accepted \\
$\mathrm{Neu} \rightarrow$ Sat & 0.076 & 1.138 & 0.255 & H1d Rejected \\
$\mathrm{Op} \rightarrow$ Sat & 0.213 & 2.481 & 0.013 & H1e Accepted \\
Ext $\rightarrow$ Per & 0.263 & 2.989 & 0.003 & H1f Accepted \\
$\mathrm{Ag} \rightarrow$ Per & -0.048 & 0.476 & 0.634 & H1g Rejected \\
$\mathrm{Con} \rightarrow$ Per & 0.154 & 1.565 & 0.118 & H1h Rejected \\
$\mathrm{Neu} \rightarrow$ Per & 0.051 & 0.484 & 0.628 & H1i Rejected \\
$\mathrm{Op} \rightarrow$ Per & 0.064 & 0.715 & 0.475 & H1j Rejected \\
$\mathrm{Sat} \rightarrow$ Exp & 0.099 & 2.076 & 0.038 & H2 Accepted \\
$\mathrm{Per} \rightarrow$ Exp & 0.619 & 8.566 & 0.000 & H3 Accepted \\
$\mathrm{Alt} \rightarrow$ Exp & 0.018 & 0.327 & 0.744 & H4 Rejected \\
$\mathrm{PS} \rightarrow$ Exp & 0.193 & 2.479 & 0.013 & H5 Accepted \\
$\mathrm{SP} \rightarrow$ Exp & -0.003 & 0.052 & 0.959 & H6 Rejected \\
\hline
\end{tabular}

We addressed how personality traits affect overall satisfaction. Certain hypotheses about the relationship between conscientiousness and openness to experience to overall satisfaction are accepted, whereas others: extrovert, agreeableness, and neuroticism have an insignificant relationship to overall satisfaction. The findings contrasted with Jani and Han (2014), who discovered that while conscientiousness and openness to experience had no link to overall satisfaction, others do. By comparison with a study done by Jani (2014) that used hotel settings as its research setting, this one looks at the impact that city tourism can have on persons with better scores in high-learning capacity (openness to new experiences) and rule-following (conscientiousness). Bujisic et al. (2015) found that persons who are more receptive to new experiences are more satisfied with different types of experiences than those who are not. The nature of the social relationship of extraversion person, avoid conflict of agreeableness person, and well-managed stress of neuroticism person might not be accommodated by city tourism which has various types of activity and options. In a typical activity like escapist experiences, social interactions and organised activity may be better created and lead to satisfaction (Bujisic et al. 2015). The lack of study in this area necessitates further tests to establish a strong link between personality traits and overall satisfaction.

Extraversion is the only personality trait that has a substantial link with perceived enjoyment, while agreeableness, conscientiousness, neuroticism, and openness to experience have an insignificant relationship with perceived enjoyment. The findings corroborated Wang et al. (2012), who also found that extraversion substantially affects subjective satisfaction in blogging activity. The findings also corroborated Wang's (2010) study, which discovered that extraversion is a major predictor of perceived enjoyment, whereas agreeableness, neuroticism, and openness to experience have no relationship with perceived enjoyment in the context of instant messaging continuation. The probable explanation was that the results were dissimilar due to cultural variations and the different contexts in which the media were used. The current study demonstrates that Indonesian visitors who exhibit stronger traits of cooperation, persistence, emotional stability, and interest in learning something new are not always motivated to share their experiences on social media. 
Overall experience satisfaction, perceived enjoyment, as well as personal fulfillment and self-actualization drive were revealed to be significant predictors of travel experience sharing activity. At the same time, altruistic motivations and security and privacy concerns have an insignificant effect on the likelihood of travelers sharing their vacation experiences on social media. The findings were consistent with Sarkar et al. (2013), who discovered a significant relationship between satisfaction and ecotourists' intention to share knowledge and Piramanayagam et al. (2020), who discovered that satisfaction with local food has a significant effect on the proclivity to speak positively and provide recommendations but contradictory with Serra-Cantallops et al. (2020), who discovered an insignificant relationship between customer satisfaction and the proclivity to spread eWOM. Oliveira et al. (2020), Kang and Schuett (2013), and Moghavvemi et al. (2017) verified the existence of a substantial association between perceived enjoyment and travel experience sharing on social media. Finally, the motivations and inhibitor variables were partially consistent with Oliveira et al. (2020) findings that altruistic motivations, personal fulfillment, and self-actualization, as well as security and privacy concerns, all have a substantial effect on travel experience sharing. Even though the relationship between security and privacy reasons to travel experience sharing has a negative value as hypothesized, the connection is insignificant. Munar and Jacobsen (2014) found that altruistic motivations drive Scandinavian tourists to contribute online but social recognition linked to personal fulfillment and self-actualization did not motivate them to do sharing. The current study provides evidence in the context of Indonesian tourists that a high level of motivation to assist others does not always compel them to contribute online and that awareness of security and privacy threats did not deter them from posting or checking in to a location on social media.

Travel experience sharing practices in social media is a form of experience co-creation between customers to customers and business to customers. The contents made could provide beneficial information for other potential tourists in planning their future trip and provide knowledge for a destination to understand how tourists perceived their experience at the destination. The study provides an exploratory effort which discovers that personality aspects of tourists did influence their experience satisfaction and perceived enjoyment to do online experience sharing experience in social media

\section{Managerial Implication}

Even though personality traits alone are not the only predictors of overall experience satisfaction and perceived enjoyment, the study results provide a fresh knowledge of the relationships among them. Therefore, destination managers could design better experience options that are sensitive to different personality features, which will drive higher satisfaction and an increasing content creator.

Destination managers, in this regard, might be Bandung City Culture and Tourism Office, travel agencies, and tourists attractions' managers could approach tourists individually. For instance, by providing a short personality traits test and the results linked to different attractions suggestions provided in Bandung city, the procedure could be done by a web-based questionnaire. This personalized service recommendation will boost tourist satisfaction. Without eliminate an introduction of all tourist attractions, the option to customized their experience in Bandung city also could be done. In this regard, goodperformance and synergies withinformation and technology should be maintained. The effective promotion could also drive tourists' intention to share their travel experience in their social media account. Socialization in the stage of travel planning and during the trip must be done by providing advertisements in form of posters and discount promotions for those who share their experience or review in their social media account by tagging the destination's account.

Providing good services is a key to gain tourists satisfaction and loyalty, even though enjoyment perception, personal fulfillment, and self-actualization reasons, and security and privacy consideration of using social media for sharing travel experience will highly depending on tourists' preference and convenience, such rewards and benefits could make them reconsider and interested in which in turn actualize the action. A good relationship, communication, sharing knowledge, understanding tourists' limitations and capabilities also could be a good way to spread and internalize the benefits of sharing their thoughts related to their experience in destination by other people. Communicate that their content is beneficial as a way to evaluate destinations' services during their experiences. The combination of an enhanced understanding and rewards could be a good strategy. An increasing number of content creators which open up opportunities for word of mouth spread and experience co-creation might come as result. 


\section{CONCLUSIONS AND RECOMMENDATIONS}

\section{Conclusions}

The purpose of this study is to build a model of overall satisfaction, perceived enjoyment, motivations, and inhibitor to sharing travel experiences, in which personality factors control satisfaction and perceived enjoyment. In this sense, the current study contributes new knowledge by incorporating personality traits in predicting overall satisfaction, which influences travel experience sharing behavior, a neglected and under-researched subject in the literature. We posit that personality characteristics can predict overall experience satisfaction and perceived enjoyment.

The findings indicate that conscientiousness and openness to experience substantially affect overall experience satisfaction, while extraversion has a significant effect on predicting perceived enjoyment to do sharing trip experiences on social media. Travelers' overall experience satisfaction significantly predicts the sharing of travel experiences at the place, perceived enjoyment, and motives for personal fulfillment and self-actualization.

The current study adds to the body of knowledge in behavioral science, particularly in the domain of travel-related content creation on social media, by considering personality characteristics, drives, motives, and inhibitors. The proposed model contributes to social media marketing and experience co-creation. Additionally, the study's findings have beneficial implications for destination management.

\section{Recommendations}

As the current study focused exclusively on the big five personality traits as predictors of the overall experience, future research might incorporate destination features as well, as Albayrak and Caber (2013) did. Additionally, the current study examined the direct effects of personality traits on overall satisfaction and perceived enjoyment and the direct effects of overall satisfaction, perceived enjoyment, altruistic motivations, personal fulfillment and self-actualization, and security and privacy concerns on travel experience sharing behavior on social media. Future research could examine the association between personality factors and the sharing of travel experiences by examining the mediating role of overall satisfaction and perceived enjoyment. The time constraint of the study enables testing of the present study only on a city-scale and in the context of city tourism. Additional research could be conducted to validate the proposed model by utilizing the different contexts to ensure generality.

\section{REFERENCES}

Albayrak T, Caber M. 2013. The symmetric and asymmetric influences of destination attributes on overall visitor satisfaction. Current Issues in Tourism 16(2):149-166. https://doi.org/10.1080/ 13683500.2012.682978

Amaro S, Duarte P, Henriques C. 2016. Travelers' use of social media: a clustering approach. Annals of Tourism Research 59:1-15. https://doi. org/10.1016/j.annals.2016.03.007

Bakshi S, Gupta DR, Gupta A. 2021. Online travel review posting intentions: a social exchange theory perspective. Leisure/ Loisir 1-31. https:// doi.org/10.1080/14927713.2021.1924076

Barclay D, Higgins C, Thomson R. 1995. The partial least squares approach to causal modeling: Personal computer adoption and use as illustration. Technology Studies 2:285-309.

[BPS] Badan Pusat Statistik. 2021. Jumlah Perjalanan Wisatawan Nusantara. Indonesia: BPS.

[BPS] Badan Pusat Statistik Jawa Barat. 2021. Jumlah Kunjungan Wisatawan Ke Objek Wisata 20172019. Jawa Barat: BPS.

Buhalis D, Inversini A. 2014. Tourism branding, identity, reputation co-creation, and wordof-mouth in the age of social media. In MM. Mariani, R. Baggio, D. Buhalis, C. Longhi (eds.): Tourism management, marketing, and development. New York: Palgrave Macmillan. https://doi.org/10.1057/9781137354358

Bujisic M, Bilgihan A, Smith S. 2015. Relationship between guest experience, personality characteristics, and satisfaction: moderating effect of extraversion and openness to experience. Tourism Analysis 20(1):25-38. https://doi.org/10 $.3727 / 108354215 X 14205687167509$

Chin WW. 1998. The partial least squares approach to structural equation modelling. In GA. Marcoulides (ed.): Modern methods for business research. New Jersey: Lawrence Erlbaum Associates, Inc.

Chung N, Han H, Koo C. 2015. Adoption of travel information in user-generated content on social media: the moderating effect of social presence. 
Behaviour and Information Technology 34(9):902-919. https://doi.org/10.1080/0144929 X.2015.1039060

Chung N, Koo C. 2015. The use of social media in travel information search. Telematics and Informatics 32(2):215-229. https://doi.org/10.1016/j. tele.2014.08.005

Devaraj U, Easley RF, Crant JM. 2008. How does personality matter? relating the five-factor model to technology acceptance and use. Information Systems Research 19(1):93-105. https://doi. org/10.1287/isre.1070.0153

Ehrenberg A, Juckes S, White KM, Walsh SP. 2008. Personality and self-esteem as predictors of young people's technology use. Cyberpsychology and Behavior 11(6):739-741. https://doi. org/10.1089/cpb.2008.0030

Goldberg, LR. 1999. A broad-bandwidth, public domain, personality inventory measuring the lower-level facets of several five-factor models. Personality Psychology in Europe.

Gretzel U, Fesenmaier DR, O'Leary JT. 2006. The transformation of consumer behaviour. In D. Buhalis, C. Costa (eds.): Tourism business frontiers: consumers, products and industry. Burlington, MA: Elsevier.

Hair JF, Hult GTM, Ringle CM, Sarstedt M. 2017. A Primer On Partial Least Squares Structural Equation Modeling (PLS-SEM). United States of America: SAGE Publications, Inc.

Henseler J, Ringle CM, Sarstedt M. 2015. A new criterion for assessing discriminant validity in variance-based structural equation modeling. Journal of the Academy of Marketing Science 43(1):115-135. https://doi.org/10.1007/s11747014-0403-8

IPIP. 2008. International personality item pool: a scientific collaboratory for the development of advanced measures of personality traits and other individual differences. http://ipip.ori.org/. [12 July 2021].

Jani D. 2014. Big five personality factors and travel curiosity: are they related?. Anatolia 25(3):444456. https://doi.org/10.1080/13032917.2014.90 9366

Jani D, Han H. 2014. Personality, satisfaction, image, ambience, and loyalty: testing their relationships in the hotel industry. International Journal of Hospitality Management 37:11-20. https://doi. org/10.1016/j.ijhm.2013.10.007

Kaihatu TS, Spence MT, Kasim A, Satrya IDG,
Budidharmanto LP. 2020. Millennials' predisposition toward ecotourism: the influence of universalism value, horizontal collectivism and user generated content. Journal of Ecotourism 1-20. https://doi.org/10.1080/14724049.2020.1 795183

Kang M, Schuett MA. 2013. Determinants of sharing travel experiences in social media. Journal of Travel and Tourism Marketing 30(1-2):93-107. https://doi.org/10.1080/10548408.2013.751237

Kemp S. 2021. Digital 2021: indonesia. https:// datareportal.com/reports/digital-2021indonesia. [14 June 2021].

Kumar TBJ, Goh SK, Balaji MS. 2020. Sharing travel related experiences on social media integrating social capital and face orientation. Journal of Vacation Marketing 1-19. https://doi. org/10.1177/1356766720975047

Liu X, Li JJ, Kim WG. 2017. The role of travel experience in the structural relationships among tourists' perceived image, satisfaction, and behavioral intentions. Tourism and Hospitality Research 17(2):135-146. https://doi. org/10.1177/1467358415610371

Moghavvemi S, Sharabati M, Paramanathan T, Rahin NM. 2017. The impact of perceived enjoyment, perceived reciprocal benefits and knowledge power on students' knowledge sharing through facebook. International Journal of Management Education 15(1):1-12. https://doi.org/10.1016/j. ijme.2016.11.002

Munar AM, Jacobsen JKS. 2014. Motivations for sharing tourism experiences through social media. Tourism Management 43:46-54. https:// doi.org/10.1016/j.tourman.2014.01.012

Oliveira T, Araujo B, Tam C. 2020. Why do people share their travel experiences on social media? Tourism Management 78:1-14. https://doi. org/10.1016/j.tourman.2019.104041

Özbek V, Alnıaçık U, Koc F, Akkılıç ME, Kaş E. 2014. The impact of personality on technology acceptance: a study on smart phone users. Procedia - Social and Behavioral Sciences 150:541-551. https://doi.org/10.1016/j. sbspro.2014.09.073

Pera R. 2017.Empowering the new traveller: storytelling as a co-creative behaviour in tourism. Current Issues in Tourism 20(4):331-338. https://doi.org $/ 10.1080 / 13683500.2014 .982520$

Piramanayagam S, Sud S, Seal PP. 2020. Relationship between tourists' local food experiencescape, 
satisfaction and behavioural intention. Anatolia 31(2):316-330. https://doi.org/10.1080/1303291 7.2020 .1747232

Ramaswamy V. 2005. Experience co-creation: the new frontier of IT. Leading Edge Forum Journal 4153.

Sarkar SK, Au N, Law R. 2013. Analysing Ecotourists' Satisfaction in Socialisation and Knowledge Sharing Intentions via Social Media. In: Information and Communication Technologies in Tourism 2014. Proceedings of the International Conference; Dublin, 21-24 January 2014. p. 313326. https://doi.org/10.1007/978-3-319-039732 23

Serra-Cantallops A, Cardona JR, Salvi F. 2020. Antecedents of positive ewom in hotels. exploring the relative role of satisfaction, quality and positive emotional experiences. International Journal of Contemporary Hospitality Management 32(11):3457-3477. https://doi.org/10.1108/IJCHM-02-2020-0113

Sorensen A, Andrews L, Drennan J. 2017. Using social media posts as resources for engaging in value co-creation: the case for social media-based cause brand communities. Journal of Service Theory and Practice 27(4):898-922. https://doi. org/10.1108/JSTP-04-2016-0080

Tripadvisor. 2016. TripBarometer 2016: traveler trends and motivations - global findings. https://www. tripadvisor.com/TripAdvisorInsights/wpcontent/ uploads/2018/01/TripBarometer-2016-TravelerTrends-Motivations-Global-Findings.pdf. [20 July 2021].
Üçok Hughes M, Bendoni WK, Pehlivan E. 2016. Storygiving as a co-creation tool for luxury brands in the age of the internet: a love story by Tiffany and thousands of lovers. Journal of Product and Brand Management 25(4):357-364. https://doi.org/ 10.1108/jpbm-09-2015-0970

Wang W. 2010. How Personality Affects Continuance Intention: An Empirical Investigation of Instant Messaging. In: PACIS 2010 - 14th Pacific Asia Conference on Information Systems; Taipei, 9-12 July 2010. p. 1160-1170.

Wang X, Li Y. 2017. How trust and need satisfaction motivate producing user-generated content. Journal of Computer Information Systems 57(1):49-57. https://doi.org/10.1080/08874417. 2016.1181493

Wang YS, Lin HH, Liao YW. 2012. Investigating the individual difference antecedents of perceived enjoyment in students' use of blogging. British Journal of Educational Technology 43(1):139-152. https://doi.org/10.1111/j.14678535.2010.01151.x

Wilson A, Murphy H, Fierro JC. 2012. Hospitality and travel: the nature and implications of user-generated content. Cornell Hospitality Quarterly 53(3):220-228. https://doi. org $/ 10.1177 / 1938965512449317$

Yi Y, Gong T. 2013. Customer value co-creation behavior: scale development and validation. Journal of Business Research 66(9):1279-1284. https://doi.org/10.1016/j.jbusres.2012.02.026

Yoo KY, Gretzel U. 2011. Influence of personality on travel-related consumer-generated media creation. Computers in Human Behavior 27(2):609-621. https://doi.org/10.1016/j. 